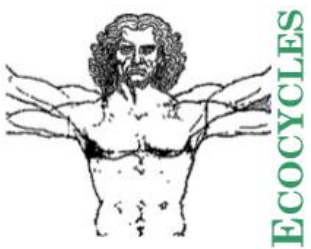

Ecocycles, Vol. 6, No. 1, pp. 1-9 (2020)

DOI: $10.19040 /$ ecocycles.v6i1.158

\title{
OPINION
}

\section{India in a changing Arctic: an appraisal}

\author{
Nikhil Pareek \\ Panjab University, Chandigarh, India \\ E-mail addresses: nikhilginni@gmail.com
}

\begin{abstract}
In the complex undercurrents of evolving new great power politics, the scheme of Arctic affairs makes for a low key affair. India in Arctic is a theme that is so inconsequential that it fails to even grab a mention. The performance of observer states in the Arctic affairs has varied substantially during these years but Indian attempts have remained short of the promise. There is immense possibility for India to build on her non-hegemonic, non-intrusive foreign policy approach to obtain a greater role in the in this strategically vital and economically lucrative region.
\end{abstract}

Keywords - Arctic, climate change, India, observer, scientific diplomacy, resources

\section{INTRODUCTION}

The Arctic, a unique region among the planet's various ecosystems is composed of glaciers, ice sheets, sea ice, permafrost, etc which make it stand out from other terrestrial forms. The Arctic region including Sub-Arctic has more than $50 \%$ of the world's wetlands and it is home to more than 21000 species of wildlife (Arctic Biodiversity Assessment, 2013). The landmass, ocean, flora, and fauna in the Arctic, is a critical intersection of economic, environmental, political, and security interests of the major global powers of today. The region has acquired global recognition and limelight in recent times due to shifting geopolitical equations and the promise of untapped resource potential and shorter shipping routes. The region's strategic importance lies in the fact that it connects three continents, which are the power centers of Global Economy, Trade and Military. This region is undergoing unprecedented and hastened, and a rather discursive transformation from being a desolate place to a region keenly watched by the Global Power States and NonState Actors.

The Arctic region also prides itself with no civil unrest, no civil wars, or any violent anti-government movements and hence the sovereign ownership of the Arctic states is paramount. The region is also a depository of immense hydrocarbons and mineral resources and there is a scramble between the littoral states to claim territories to commercially exploit these. The indigenous people of the Arctic have a distinct and historical connection of livelihoods wherein their goals are directed at the economic and social development of their communities sustainably while preserving the traditional ways.

Lately, three prominent themes have emerged in the regions which are threatening to tilt or disrupt the current structures namely Climate Change, Post-Cold War Geopolitics between the West and Russia and emergence of China as a Global power with high aspirations. The powers, even those that are politically and geographically far away from the Arctic, have been making calls claiming their respective stakes in the Arctic for reasons of self- interest and citing the wider global implications of climate change. The increaseingly assertive geo-economic and geostrategic role of China is already raising eyebrows in the USA and other Arctic states and some quarters are even warning of a likelihood of a conflict in the future. Though, certain hypotheses have predicted that the rush for resources will push the region to the brink of conflict yet the precedent indicators testify to the mature and peaceful resort among the Arctic8 (USA, Russia, Canada, Norway, Sweden, Finland, Iceland, and Denmark) to resolve the differences among them, peacefully. The inclusion of nonArctic observers including States, Intergovernmental/InterParliamentary Organizations and Non-Governmental Organizations in the Arctic Council (AC) has contributed to 
a discursive transformation, putting the region into the international limelight.

\section{INDIA'S CONNECTION}

A Consultative Party of the Antarctic Treaty, India's research endeavors in Antarctica started in 1981 and Bharati Research Station was established on the continent in 1983. Based on this Polar Scientific activity, as well as the teleconnections between the Arctic region and Indian monsoon intensity, India turned its attention to the Arctic. In the Arctic domain, India had signed the Spitsbergen Treaty in 1920, accepting Norwegian sovereignty over Svalbard Islands. India had established its research presence in the Arctic since 2007 and established the research station 'Himadri' in 2008. India was granted observer status in the Arctic Council in 2013 along with China and 3 other Asian countries. After inclusion as an Observer, India listed its' interests in the Arctic region as scientific, environmental, commercial as well as strategic (MEA, Government of India, 2013). In the same breadth, India also called for the participation of all those actors who have a stake in the governance of Global Commons (MEA, Government of India, 2013).

In India, a developing country with a huge population still dependent on agriculture, the availability of water for agriculture is a livelihood concern. The receding glaciers in Himalayas and ice loss are impacting the downstream availability of water, imperiling lives. Indian Scientific efforts in Polar Regions are in this direction to understand and corelate the Geology, Climate, and Hydrology of Arctic Glaciers and the resultant changes experienced in the Himalayan glaciers due to ice shrinkages. India is concerned about the negative impacts of reduction in ice caps in the Arctic which will have a devastating effect on the IndoGangetic plains and disrupt agricultural production and trigger natural calamities and disasters. Concurrently, India is a major energy consumer and is keenly awaiting the opening of new, shorter passages connecting Asia to Europe.

India has relied on its Antarctic experience for formulating a vision for the Arctic, which perhaps partly justifies the reason for certain lacunae in her position. Some sections of Indian intelligentsia have repeatedly viewed the Arctic through the Antarctic prism although the geopolitical and politicoeconomic circumstances in these two regions are 'poles' apart. Though India is yet to formally chart out its Arctic Policy Framework for greater and transparent engagement yet it enjoins goodwill, and trust to proactively and constructively chart out its national interest objectives in the region. 'Indian policy discourse has yet to produce a coherent or dominant opinion on the country's place in Arctic affairs' (Lackenbauer, 2013). 'Though the Arctic littorals are broadly viewing their territorial and economic claims by rights enshrined under International Law and Treaty obligations, India has claimed to be a stakeholder by understanding and analysis of the complex and fluid contexts in which the discourse and practices of Arctic Governance are being debated and shaped at present' (Lackenbauer, 2013).
The granting of observer status to 5 Asian countries in 2013 was an acknowledgment of the growing economic and political significance of these countries, yet in the last 6 years, the progress among these 5 nations has varied substantially. While China has made progress by leaps and bounds, India remains lackluster. This environmental transformation of the Arctic region, hastened by Climate Change will have a profound impact on commercial exploitation of resources, shipping patterns, and trade, and will present a mixed bag of opportunities and challenges.

India, since its admission in the AC, has been focussing on Scientific Engagement, without precisely articulating its strategic interests. There are fears that great power rivalries, often by matters outside the Arctic may manifest in Arctic affairs, unduly skewing the environment. The India-China relations will also have to stand this test. The current situation prevailing in the Arctic from an Indian viewpoint is:-

\section{Playground}

In a truly interconnected world, the future of the Arctic may depend at least partially on whether growth in China and India is sustainable. India's interests in the Arctic can be summarized regarding fulfilling its Energy Security, Opening of new routes, impact on natural resources due to climate change and growing international competition. There is a divergence in India's gains with the changing Geo-Economic stature of the Arctic as India's edge in enforcing its military doctrine on China is getting eroded with the opening of NSR (Northern Sea Route) as also the operationalization of 'Power of Siberia' and other Sino-Russo economic and energy ventures. However, India possesses an inherent advantage as a counterbalance to China, which is being viewed increasingly with suspicion and skepticism in the region. The US Secretary of State, Mike Pompeo had called the region "an arena of global power and competition" in May 2019 (Washington Post, 2019) and likened China's developing strategies in the Arctic Ocean which were similar to those in the South China Sea (US Embassy, 2019).

Till now, the strategic rivalry between India and China was witnessed in areas of Border disputes, Sea-power, and Trade but the Arctic can spiral this rivalry to newer dimensions of Energy Security and access to sea routes. In the short term, India though can draw solace from the fact that countries skeptical of China will put their bets on India. Because of this, when engagement in the Arctic is at nascent stage and battle lines yet to be drawn, it will be prudent for India to broaden its engagements both bilaterally with Arctic nations as well as through the mechanism of AC.

\section{Transition}

In light of the immense possibilities emerging from the increasing accessibility options and unlocking of the Economic, Commercial and Strategic potential of the Arctic, parallel yet grave problems will be encountered for both the mankind and international community. There has to be a judicious balance between the exploitation of resources for the economic development of the population and protecting the pristine Arctic environment. It is now established that 
developments in the Arctic will have telling effects across the globe, manifesting in rising sea levels, changing weather patterns and unpredictable climate catastrophes. The race to obtain a legitimate stranglehold on the Arctic Region between the Global powers and aspiring powers is underway. Another dimension of the ecological changes is manifesting in the opening of newer sea routes and passages, exponentially reducing the distances between the geographically apart regions. The Arctic is and should remain a region of low tension with a high degree of international cooperation based on International Law and the 2013 Vision for the Arctic (Huff Post, 2019).

\section{India's contribution to the cost of Cold development}

Given the foregoing, it is abundantly clear that a very difficult choice has to be made by the world community at large between economic development achieved by extraction and exploitation of the huge natural resources in the Arctic and to preserve the last bastion of pristine and bountiful natural wonders. A well thought out and deliberate balance has also to be struck between seeking energy supplies and profits from hydrocarbons and on mitigating the environmental deterioration, exacerbated due to the former actions. It appears that India's current Arctic policy is caught between the two opposing and divergent poles of it being a responsible member of the international community with focus on parity and proportionate burden-sharing in climate change and contrarily on being a developing country with immense demand for energy resources and wanting to benefit from the emerging opportunities in the Arctic.

\section{Global Commons}

Some Indian commentators on the Arctic presented a view centered on the 'polar race' narrative and presented an 'unbalanced and highly alarmist portrait of a region on the precipice of conflict' (Lackenbauer, 2013). Another commentator viewed the Arctic as a global commons and argued that 'AC observer status is tantamount to accepting the sovereign rights of the AC members over the Arctic Ocean' (Lackenbauer, 2013). Both Arctic5 (Arctic Ocean littoral states) as well as Arctic8, will oppose any move by nonArctic states to demand such rights and the same was enunciated by the 2008 Ilulissat Declaration by the Arctic littoral states.

\section{Russia-India Partnership, 2019}

2019 has been a remarkable year for invigorating and giving a concrete dimension to the Russia- India Energy Partnership. Both the countries are adopting a road map to establish a "Far Eastern Energy Corridor" that would boost Russian Oil, Gas and Coal exports and trade to India. A Memorandum of Intent was signed between the Ministry of Shipping of the Republic of India and the Ministry of Transport of the Russian Federation on the Development of Maritime Communications between the Port of Chennai, Republic of India and the Port of Vladivostok, Russian Federation in September 2019. The joint declaration paves the way for the mutual benefit of both the countries as Russia will get to diversify its energy customer base and India will gain by reducing its dependence on her traditional suppliers. Because of the ongoing friendly partnership between India and Russia, backed by strong Political and Economic will this deal promises tremendous opportunities to both the countries. The fact that India does not harbor any geopolitical ambitions will also propel the partnership to greater orbits.

The prospects, viability and likely benefits of the Vladivostok-Chennai route will be clarified with the progress of the circuit, which promises a reduction of around 15 days of travel. Additionally, there are no disruptions like Piracy, etc in this route, though Chinese interference at a later stage can't be deciphered with certainty in the present timeframe. The progress on expanding hydrocarbons trade between the tested partners though appears to be delayed but is a step in the right direction. The signatory corporations and entities must develop the agreements to lucrative and profitable ventures as the foundational basis has been provided at the governmental level. Since Russo-India cooperation in other fields like Defense, Cultural, and Technical has already proved fruitful and is backed by firm political backing, there should be minimal barriers in fulfilling these economic and energy goals.

Eurasia is likely to remain an important center of global geopolitics and a major region having immense hydrocarbon potential. India has to balance its strategy, association, and dialogue with Russia and the USA in a way so that the other partner is not antagonized and a strategic balance is maintained.

\section{Governance}

The Arctic region can pride in having multitudes of cooperative organizations having tiered membership as well as mandates. 'This is so for the Arctic strategic landscape as it is premised on a Latent Balance of Power - defined by the region's geographic division of authority, strategic alignments, and state coherence - that has ensured territorial security, neutralized contests over hegemony, and facilitated the emergence of a decentralized but robust regional order'. (Macdonald, 2019). However, a problem with the Arctic Council is that it has always been a soft law regime, and there has never been any intention to create legally binding obligations for the Arctic states. (Lennon, 2008). This, however, does not take away the tested course of organized cooperation on common interests in the Arctic region that will rather lessen the strategic rivalry of competing nations.

\section{Observers}

Council observers are less influential than states in the Council. Member states accept observers to make economic gains. 'Non-Arctic states are interested in protecting the environment as well as making potential economic gains, in contrast to the more focused motivations of member states (Chater, 2016). While signing the AC admission norms as an observer, each of the Observers States has acceded to abide by the governance structure, which offers the right to vote and voice on matters only to the circumpolar member states. There is another dilemma here wherein the adherence to UNCLOS claims specifically lowers the space for international scientific research as the area becomes sovereign 
territory with sovereign rights becoming applicable and the call for global commons is deflated.

\section{Climate change goals}

Though the countries of the world profess to adhere to the lofty goals of Paris climate goals, yet the global energy demand and carbon emissions have been growing at a faster pace, meaning that lip service is being paid to the emission and pollution reduction. The associated effects of that the current pace of growth is acutely swelling the rising emissions, which in turn lead to unpredictable weather patterns and thereby far greater energy for cooling and heating. India possesses a scientific base and structures to progress the climate change goals yet her international cooperation on Climate Change falls short of the promise.

In August 2015, the USA convened GLACIER (Global Leadership in the Arctic: Cooperation Innovation, Engagement, and Resilience) conference to highlight the most urgent issues facing the Arctic, as well as innovative approaches at the local, national and international levels to addressing the region's challenges. India and China, however, didn't sign the joint declaration at the end of the conference, hence raising questions on their commitment to slow the pace of global warming, with effects in the Arctic.

In the recently concluded COP25 summit, both India and China along with the USA and Brazil have also backtracked from Climate Change promises. The intransigence of big polluters - including China, the US, Brazil, and India - at the meeting led to the European Union, the Small Island States and members of the public expressing frustration (New Scientist, 2019). This ironical dichotomy of call for action on issues like climate change and concurrent material progress and development related activity linked to receding ice cover in the Arctic in itself calls for a well thought out and robust action plan in the world community.

$\mathrm{CO}_{2}$ emissions by India stand at number 3 in the world after China and the USA and this lays tremendous responsibility as India vows to accede to climate change goals, which is a difficult path as the country is still on the path of economic growth. An analysis by Climate Action Tracker shows that India can achieve its NDC (Nationally Determined Contribution) target with currently implemented policies. (We) project the share of non-fossil power generation capacity will reach $60-65 \%$ in 2030 , corresponding to a $40-43 \%$ share of electricity generation. India's emissions intensity in 2030 will be $\sim 50 \%$ below 2005 levels. Thus, under current policies, India is likely to achieve both its $40 \%$ non-fossil target and its emissions intensity target' (Climate Action Tracker, 2019).

Hence India is occupying a position different from the USA and China and can assume the leadership position by showing its tangible commitments to the world and Arctic nations in particular. All stakeholders are engaging the Arctic region, multilaterally and bilaterally through dialogue, treaties, regulations, and incentives, to ensure that the impacts of climate change and environmental degradation are curbed and the region develops sustainably.

\section{Chinese Tilt}

India, due to its geo-strategic location should view the Arctic from a different perspective as the conditions favoring China do not apply to her. The economics of shorter routes and savings of time, in the case of India, are not so different from the existing southern routes than the Arctic ones. Hence its considerations have to be abreast of the reality that unlike gains that accrue to North-East Asia, her situation doesn't merit greater windfalls.

China is pumping huge sums in infrastructural development in the Arctic and has charted that it's Polar Silk Road will incorporate the Arctic states in its realm. Since India does not possess the financial muscle to match the Chinese investments, a strategy to question the Chinese attempts in Greenland and Iceland, as happened in Hambantota of turning the small counties into strategic vassals through debt-trap diplomacy will have to be addressed both at bilateral and multilateral fora in the Arctic region.

\section{Investments}

It is assessed that India's lukewarm response to Russia's calls for investments in its Arctic oil and gas projects will further tilt the geopolitics of energy in favor of China and other European countries. In any case, the European market has been a priority for Russia, since it brings Russia both economic and geopolitical benefits as well as its relative geographical proximity. Russia views its energy resources as a key strategic asset. India was allowed to invest in the Sakhalin-1 project on very favorable terms because of political considerations.

India must get involved in Eurasian Oil and Gas projects, not only for its energy security but for political and strategic considerations since Eurasia is likely to remain an important center of global geopolitics. 'As a long-time trusted friend and strategic partner of Russia, India could expect Russia to be positively inclined towards its quest for access to Eurasian energy' (Sikri, 2008). Since India's energy demand is met by foreign sources as her indigenous production and finds are minuscule as compared to her consumption, India has to carefully balance energy supply, energy mix, and energy sources.

\section{Lack of Strategic Vision}

The Indian Foreign Policy, which is often a highly individualistic affair and shifts with the focus and orientation of the top Indian Foreign Service officers and also carries the idealistic and ideological framework of the Nehruvian era. Indian Foreign officers are given a high level of autonomy and allowed to make individualistic decisions, which result in bottom-up foreign policy that lack a long-term view and strategic vision (Tonami, 2016). The wide rift between Chinese engagements in the Arctic which had joined the Arctic Council with India in 2013 is demonstrative of the fact that Indian Policy suffers from lack of a continued long term view and is often found following in others' footsteps. 


\section{Polar Research Vessel}

A massive void in the Indian scientific pursuits is that India does not possess a polar research vessel or an icebreaker and has to rely on chartered vessels seriously limiting its research timeframe as well as a huge economic drain. This cleft in the professed research narrative despite having a physical presence for over 3 decades and the proposal for acquisition of a Polar Research Vessel having been approved in Jun 2010 but is yet to materialize. This belated and nonchalant response is impinging on the scientific efforts and also manifests in scanty Indian research of reputable standards.

\section{RECOMMENDATIONS}

\section{Arctic Actorness}

The other Arctic observers like China and the UK have tried to justify and fit in their respective stakes by situating 'NearArctic' and 'Sub-Arctic' in their policy statements, respectively. Though there are historical and cultural links as stated in the Hindu religious scriptures Vedas, mentioned by Bal Gangadhar Tilak in his 1903 work 'The Arctic home in the Vedas' describing the Arctic region as cradle of human race, India has not established any sound basis for her engagement, other than pursuit of scientific studies and research.

\section{Emphasis on scientific diplomacy}

Science can play a larger role in shaping the foreign policy and mold interstate relations and thus is an invisible organ of the state power to extend its reach. Scientific endeavors and its enlargement into avenues like opening new research stations and participating in multi-institution research projects like Multidisciplinary Drifting Observatory for the Study of Arctic Climate (MOSAiC) can cement the legitimacy of one's national claims. Other than conducting valuable research to understand and share the climatological, environmental, and other scientific disciplines, scientific diplomacy also establishes trust and understanding and enhances cooperation. The research bases also act as pillars of geopolitical engagement and scientific diplomacy can prevent conflict situations. 'Collaboration and data sharing concerning Arctic research stations are key instruments for integrating rising Asia in the Arctic in a peaceful way' (Goodsite et al., 2016).

It is due to scientific cooperation that rising Asian powers including India have been quietly included in the Arctic region. In effect, 'states and institutions are applying science as a tool of diplomacy to demonstrate presence in the Arctic Ocean and to foster cooperation independent of political, economic, or cultural dynamics' (Gautier, 2009). The efforts at continued scientific diplomacy should be promoted by way of joint research in climate change and a changing Arctic environment due to climate-induced factors. The focus on Geography, Climatology (especially Climate Change), Geology, Glaciology, and Oceanography must continue along with newer avenues like digitalization efforts, laying of Submarine cables and so on.

\section{Climate change}

The warming Arctic will have disastrous, unyielding and unprecedented effects on sea levels, the onset of droughts and floods and consequent drastic impact on crop yields all across the globe. Climate Change had a role in converting the Arctic from a flourishing habitat of woolly mammoths and other now-extinct animals to a barren desolate place.

There is a need to fight climate change at all levels. There must be strong measures at the international level, supplemented at the regional level, under the framework of UNFCCC to weed out industrial pollutants that will go a long way in addressing some issues. India can no longer expect to rely on mere promises to curb environmental pollution, reduce GHGs and so on. Neither the passive presence in polar research stations like Himadri alone is going to make up for concrete actions that it must make to establish its credentials as a responsible power committed to a Green Earth.

\section{Conservatism in Indian Policy}

The dominant narrative in India's Arctic policy remains focused on Science and scientific research which is conservative in its outlook. The changing geopolitical landscape in the Arctic though, demands that sustainable development of resources while remaining alive to the looming dangers of environmental degradation are addressed by all stakeholders, including India. 'India's reluctance to deemphasize its scientific interest towards a more calibrated approach that takes into account the Politico-StrategicEconomic dimensions in the Arctic reflects the tension between the exceptionalism and the realism of its polar legacy' (Sinha, 2019). The conservatism is also marked with a myopic view in which the policymakers are shy to take a broad and long term view of the exceptionally grave challenges that are being thrown up by Climate Change in the Arctic. India's policy on Arctic engagement has centered around restrained caution till now. It is high time that this is transformed into a firm assertion with clearly defined goals and outcomes.

\section{Formulate Official Policy (Framework)}

Both Korea and Japan had preceded China in issuing out a comprehensive Arctic policy. China had released its white paper on the Arctic in January 2018. One common attribute among these policies is an alarm on receding ice and environmental protection, scientific research, support to indigenous communities, and unlocking economic opportunities. The Indian Government may still be reeling under the Ilulissat Declaration of 2008, which had unequivocally protested/admonished outside interference in Arctic Affairs. Notwithstanding, the global ambitions that India nurtures requires that it states its vision to be declared and effectively communicated to all concerned. Though the Arctic states have preferred to keep non-Arctic states at an arm's length but with greater globalization and integration, it is imperative to formulate lasting partnerships by transparent and open communication.

India needs to become diplomatically active by forging alliances to become a reckonable force. Though the economic 
and commercial benefits of the shortened transit passage of NSR does not impact India as much as to North-East Asian states due to its geographical location, yet there are more pressing issues like GHG emissions, climate change, ice cover recession, etc. impacting the Arctic, on which India's policy is keenly awaited and sought by the AC states and others.

In terms of semantics, India has to be careful in drawing out a policy framework/white paper rather than a strategy as some of the sovereign states of the AC may feel embittered if a strategy is put across by a non-member over territories under their jurisdiction.

This policy (framework) document should bring out the priorities, key focus areas and commitments of the Indian government for a mutually beneficial lasting partnership. This document will have to focus on coordinated action based on best practices and hope for a better and sustainable future for humankind. This will also entail regular revisions, in line with changing geopolitical environment and modifications by the Indian government, to suit her requirements. This is critical, as there is no domestic control over international events and the environment, which is ever-changing.

\section{Third Pole Vision}

India can derive parallels between its Antarctic expedition's scientific expertise and legacy as also as the geographical state having the Third Pole, the Himalayas in its backyard to boost its credentials. However, the dimension of the Third Pole remains conceptual and India has not been able to integrate this into the broad Arctic discourse. India can put forward the Arctic governance example to build trust and foster intergovernmental cooperation to bring together India, China, Nepal, Pakistan, Bhutan, Afghanistan and also Myanmar and Bangladesh, among nations that are impacted by the developments in the Himalayan-Third Pole region. Among these nations, India and China have been enriched by the observer status in the AC and can bring forth the insight and experience for the region's benefit.

\section{Define Energy Needs / security}

In the era of liberal globalization, the relationship between nations hinges on the ability to fulfill the energy demands and India being a growing consumer has to diversify its energy matrix. India currently imports more than $80 \%$ of its energy requirements and predominantly it is sourced from the Middle East including Saudi Arabia, Iran, Iraq, and others. A safe bet to ensure against future geopolitical risks, and to ensure regular and assigned national energy requirements, is to draw out the Arctic as a major future source.

\section{Perception Building of benign Indian interests}

The Indian diplomacy has to its credit few attributes like being non-hegemonic, non-prescriptive and non-intrusive. India has chosen not to be overly and overtly assertive in its dealings and statements, and there is an immense possibility to build on this benign and mellow approach as being friendly and alive to the local issues and not resource hungry to the detriment of the Arctic8.

\section{Role of Indian Navy}

The Indian Navy (IN) has been involved in securing the sea lanes of communication (SLOCs) in the IOR, and with the Indian Energy supplies shifting, though marginally, to the Arctic, a newer dimension of security risks will unravel. Because of reduced Chinese reliance on Southern straits, the IN will have to seek newer avenues of incorporating and formulating a role in the Arctic routes. The efforts of IN in piracy control in the Arabian Sea and Africa has won accolades and even if NSR and Arctic shipping becomes voluminous, it will not diminish the potential of traditional Europe-Asia routes and with US and China playing out in the Indo-Pacific, the role of Indian Navy is well charted out.

\section{Central Role}

India can pride herself on certain essential parameters like the largest successful democratic model, phenomenally large economy and even larger population and being a role model for growing economies and developing countries. It also harbors an aspiration to play an increasingly central role on the world stage, for which India is striving to obtain a United Nations Security Council seat. India has also carefully balanced its growing energy requirements with deftness and it has to evolve a determined, coordinated and sustained longterm strategy to ensure its energy security because of the changing dynamics of the opening of Arctic shipping lanes and access to Arctic resources. It is prudent that India's neighbors be co-opted in a broad strategy so that no only India's position is strengthened but the resources are not monopolized by certain countries alone. It will pay handsome dividends to assume support of Asian partners and assume a leadership position in sustained deliberations to obtain a lucrative and mutually beneficial arrangement.

\section{Bilateral and Multilateral Means of engagement}

Considering the geographical distances and legal regimes, it will be prudent for India to take the path of cooperation with the coastal Arctic states in exploiting the energy and other resources located within their uncontested EEZs. As an observer nation, India must advance the Council's work by financing select projects and contributing India's expertise on issues affecting the region. Countries like Norway, Sweden, Japan, and South Korea are significant players in providing India a foothold in strategic calculations. The FTAs and trade talks with these countries should be enlarged to include maritime logistics agreements, maritime transport, and technologies. India should reaffirm its commitment to the sovereignty of the Arctic nations and build mutual trust using compliance with international law and mechanisms to redress any differences and conflicts.

Since the AC governing rules impose restrictions on participation by the observers, the means to engage in meaningful dialogue and collaboration with the members on a bilateral basis will prove to be more effective. 'China has pursued such a strategy in recent years, individually courting the Arctic Eight to position itself as an indispensable Arctic player (Rainwater, 2016) 


\section{Rivalry with China}

Both India and China have been vying for resources, especially hydrocarbons and there is a risk that the quest between these two may hamper the multilateral engagement in the Arctic. India realizes that Intra Asia competition pits her against its main regional rival, China and calculated and measured attempts by India will go a long way in propelling India's ambitions in the Arctic. The key for India lies in nonmilitary cooperation in fields like scientific and cultural with the Arctic states and assume a leadership role to fight climate change.

India has to its benefit enjoyed the support of countries in the High North on critical issues, including its permanent membership to UNSC and other areas. Closer ties to hightech Northern European economies promise great rewards for India in a variety of sectors, including clean energy, communications, and defense.

\section{Geothermal Cooperation}

Towards the goal of making India self-reliant in its energy requirements, an ambitious goal is to gradually switch over to renewable energy. The leadership position enjoyed by Nordic states in geothermal energy should be leveraged to build and develop India's geothermal plants. The progress undertaken by the Indian side is snail-paced and it must develop it expeditiously to engage the Nordic partners commercially on a bilateral basis.

\section{Manpower}

India should exploit the demographic dividend of large, qualified and skilled workforce to assist in projects to develop ports and extract minerals from the rich Barents and circumpolar regions. This has already been discussed and agreed during the Vladivostok Eastern Economic Forum plenary and has to be developed further.

\section{Interdisciplinary Research Disciplines}

Around 60 scientists from 18 national institutions, organizations and universities have participated in the Indian Arctic Program. Other than scientific disciplines, Arts, Cultures, Films, newer media and knowledge domains should be progressed so that there is greater understanding and response between India and Arctic8. 'Proactive participation by India in the Arctic Council could prove to be a major catalyst for introducing legal-political innovations within the global knowledge commons' (Chaturvedi, 2013).

\section{Fears of China}

NATO, for the first time in the history of the alliance formally acknowledged the "opportunities and challenges" posed by China's increasing global role. 'We have now, of course, recognized that the rise of China has security implications for all allies. They recently displayed a lot of new modern capabilities, including long-range missiles able to reach all of Europe, the United States (DW.com, 2019). The malignant fears of the Chinese offer a contrarian advantage to India provided it projects itself as a serious partner for Economic, Cultural, Scientific cooperation and uses this to her advantage. India by its policies of cooperation and joint confidence-building has been a preferred and trusted ally of the Arctic nations. However, in the event of growing skepticism by Arctic nations in the wake of certain aggressive policies of others, India may also be made to pay the price. China holds the key to this discourse in the wake of certain statements by Arctic 8 leaders and its overly ambitious policies.

India must draw out lessons from the Chinese experiment in the Arctic, where there is skepticism of its policies and interests in the Arctic, visible by the testimony of Stephanie Pezard, presented before the Standing Committee on Foreign Affairs and International Development of the Canadian House of Commons on November 26, 2018 (Pezard, 2018). Some sections are preparing for greater involvement with the growth of Chinese investments and economic involvement, which is raising heckles. Also, China's large investments need to be secured, and economic involvement might eventually lead to some form of military presence (Pezard, 2018).

\section{Oil and Gas}

One of the reasons for lackluster Indian participation in equity participation in Arctic hydrocarbon resources can be attributed to the uncertainties associated with the exploitation in the tough Arctic conditions and sanctions regime imposed by the Western powers on Russia and also due to the dropping oil prices which may negatively influence the Arctic energy projects implementation. The predictions concerning undiscovered Arctic oil and gas resources have a significant margin of uncertainty and it may be prudent from the Indian perspective to participate in similar projects in Africa, South East Asia or Latin America which have a greater degree of certainty and easier exploration. A balance has to be drawn by India between its quest for secure energy supplies and as a responsible state, committed to standing by its promise of preventing further environmental damage, pollution and potential fight for resources in the sensitive Arctic region.

\section{Arctic Ambassador}

In the Arctic Circle assembly of 2019, India was the only exception that didn't depute any Ambassador/Special Representative unlike China, Japan, and Korea. It is vital to have a person, with established and respected credentials to portray India's position. The Arctic ambassador will also be the voice for Arctic and Indian connection at other forums like SAARC, BIMSTEC, IBSA, etc. to garner the attention of these multinational forums and also emerge as a strong voice for Arctic affairs and thereby gain the trust of the Arctic nations.

\section{Counterbalance / Co-opt China}

The opening of NSR and China accessing oil from the North will also deprive India (and the USA) the strategic leverage on choking/controlling the Malacca and other Southern straits. The most strategic advantage the opening of NSR will offer to China will be diversifying its energy supply routes and reduce dependence on disputed chokepoints like the straits of Malacca. Over and above this, there will be substantial cost and time saving as the distance and time 
between North- East Asia and Europe will be substantially narrowed. Quite like the Japanese and Koreans, the Chinese shipping and shipbuilding industry will also stand to gain with increasing traffic in the NSR. It is well acknowledged that mutually beneficial economic cooperation can assuage strained relations between mature nations. Both India and China are accorded observer status which entitles them to know the policy and direction of the deliberations of the AC member states. The concerted and joint interaction will logically not only assist both countries in the Arctic region but also serve to reduce tensions elsewhere.

\section{Conclusions}

India has a long tradition of public debate and intellectual pluralism. 'Addressing complex problems through reasoned dialogues and accommodating conflicting views and perspectives are ingrained in Indian culture, which results in constructive debate and dialogue '(National Maritime Foundation, 2019). Because of the stated Indian position of non-hegemonic and non-aggressive stance, it may be worth considering to co-opt China and progress not only the scientific but eco-strategic dimension of the changes in the Arctic region. Since developments in the Arctic will have a tremendous impact on international economics, trade, climate change as well as research and technology it is vital to be involved in the framework for enhancing India's leverage and voice. There are interconnected issues like freedom of navigation, control of straits, adherence to UNCLOS, dispute resolution, etc. involving countries with whom India has traditional and historic friendship hence the view adopted by India will have considerable merit.

The Arctic states and the AC along with its associated fora have been successful, especially in times where great power rivalry and inter-regional maneuverings were rampant in isolating and insulating the region from these dynamics. This speaks a lot about the farsightedness in evolving $\mathrm{AC}$ with considerable clout in Arctic affairs and binding the Arctic8 in areas of mutual interest. These efforts must be reinvigorated and emphasized so as let AC is a torchbearer in regional leadership and a cooperative framework and a model to emulate. India, by its democratic heritage and collaborative lineage, fits the requirements of an external observer state and must continue to build on its strengths for obtaining a leadership position in this strategically vital and economically lucrative region.

\section{References}

Arctic Biodiversity Assessment (2013): Status and Trends in Arctic Biodiversity

https://portals.iucn.org/library/sites/library/files/documents/ Bios-Eco-Ter-Pol-028.pdf (accessed on 22 Nov 2019)

Chater, A. (2016): Explaining Non-Arctic States in the Arctic Council, Strategic Analysis DOI: $10.1080 / 09700161.2016 .1165467$

Chaturvedi, S. (2014) India's Arctic Engagement: Challenges and Opportunities, Asia Policy18, 73-79.
DOI: //doi.org/10.1353/asp.2014.0037

Climate Action Tracker (2019)

https://climateactiontracker.org/countries/india/ (accessed on 27 Nov 2019)

Dw.com, (2019): https://www.dw.com/en/nato-recognizeschina-challenges-for-the-first-time/a-51519351 (accessed on 12 Nov 2019)

Huff post (2019) : https://www.huffpost.com/entry/whathappens-in-the-Arctic-does-not-stay_b_7445208 (accessed on 03 Nov 2019)

Gautier, D. L., Bird, K. J., Charpentier, R, R., Grantz, A., Houseknecht, D. W., Klett, T.R., Moore, T.E., Pitman, J.K., Schenk, C.J., Schuenemeyer, J. H., Sorenson, K., Tennyson, M. E., Valin, Z.C., Wandrey, C. J., (2009): Oil and Gas Resource potential North of the Arctic Circle, Geological Society, London, Memoirs, 35, 151-161, 2011

DOI: https://doi.org/10.1144/M35.9

Goodsite, M. E., Bertelsen R. G., Pertoldi-Bianchi, S. C., Johannson, H., Der Watt, J.R.L., (2016): The Role of Science Diplomacy: a Historical Development and International Legal Framework of Arctic Research Stations under conditions of Climate Change, Post-Cold War Geopolitics and Globalization/Power Transition

DOI 10.1007/s13412-015-0329-6

Lackenbauer, W.P. (2013): India's Arctic Engagement: Emerging Perspectives, Arctic Year Book: 2013

https://Arcticyearbook.com/Arctic-yearbook/2013 (accessed on 11 Sep 2019)

Lennon, E. (2008): "A Tale of Two Poles: A Comparative Look at the Legal Regimes in the Arctic and the Antarctic." Sustainable Development Law and Policy, Spring 2008, 3236, 65-66.

Macdonald, A.P. (2019): Precarious Existence or staying the Course? The Foundations and Future of Arctic stability, Arctic Year Book 2019

https://Arcticyearbook.com/ (accessed on 02 Oct 2019)

Ministry of External Affairs, Government of India (2013): India and the Arctic

http://www.mea.gov.in/in-focusarticle.htm?21812/India+and+the+Arctic/ (accessed on 24 Oct 2019)

National Maritime Foundation (2017): India and China, Exploring convergences in Asia http://www.maritimeindia.org/View\%20Profile/Book\%20N MF\%20AWW\%20Dialogue\%202.pdf (accessed on 16 Oct 2019)

New scientist (2019) 
https://www.newscientist.com/article/2227541-cop25climate-summit-ends-in-staggering-failure-of-leadership/ (accessed on 17 December 2019)

Pezard, S. (2018), The new geopolitics of the Arctic: Russia's and China's Evolving Role in the Region.

DOI: doi.org/10.7249/CT500

Rainwater, S. (2013): Race to the North: China's Arctic Strategy and its Implications, 66 NAVAL WAR C. REV. 62, 76

https://digital-commons.usnwc.edu/nwc-

review/vol66/iss2/7/ (accessed on 18 Sep 2019)

Sikri, R. (2008): The Geopolitics of Energy Security and Implications for South and Southeast Asia, ISAS. https://www.files.ethz.ch/isn/48142/36.pdf (accessed on 15 Dec 2019)

Sinha, U. K. (2019): India in the Arctic: A multidimensional approach. Vestnik of Saint Petersburg University.
International Relations, 2019, vol. 12, issue 1, pp. 113-126. http://vestnik.spbu.ru/html19/s06/s06v1/07.pdf (accessed on 27 Oct 2019)

Tonami, A. (2016): Asian Foreign Policy in a changing Arctic, The Diplomacy of Economy and Science at New Frontiers, Palgrave Pivot, 2016, ISBN 978-1-137-53746-1 (eBook)

DOI 10.1057/978-1-137-53746-1

US Embassy (2019)

https://ee.usembassy.gov/press-availability-at-nato-foreignministerial-2019/ (accessed on 02 Nov 2019)

Washington Post (2019)

https://www.washingtonpost.com/world/nationalsecurity/pompeo-warns-of-dangers-of-russian-and-chineseactivities-in-the-Arctic/2019/05/06/e2e99690-7001-11e99eb4-0828f5389013_story.html (accessed on 11 Nov 2019) 